\title{
The assessment of knowledge economy efficiency: comparing Turkey with the European Union countries* $^{*}$
}

\author{
Tuba Yakıcı Ayan ${ }^{1}$, Hakan Pabuçcu
}

\begin{abstract}
Knowledge economy is an economy that produces, distributes and uses information. Nowadays, investment in quality information rather than capital inputs is becoming more and more important for countries to develop and to be able to compete with each other. The increasing speed in the creation and spreading of knowledge has made it a crucial component in economic development. It is a fact that the countries that make large investments in information factors experience a fast and sustainable growth and are the most dynamic and competitive countries in the world. In this paper, we use context dependent DEA to measure the relative efficiency of the European Union (EU) countries', including Turkey, knowledge economy policy based on 2016 data. In addition, we implement factorspecific DEA in order to identify achievable targets in short term for each output of countries. Four outputs and three inputs were used in the analysis. The results showed that Germany is clearly ahead of other countries such as France, England, Malta and the Netherlands. Turkey, on the other hand, separates from other countries and is the least efficient one. The reason for this separation is that Turkey produces less output than expected relative to its facilities. Another conclusion of the paper is that the countries' patent applications and high-tech exports are more inefficient than other knowledge economy outputs.
\end{abstract}

Key words: knowledge economy, efficiency, context dependent data envelopment analysis, factor-specific data envelopment analysis

JEL classification: C61, O57

\footnotetext{
* Received: 19-02-2018; accepted: 27-11-2018

1 Professor, Dr., Karadeniz Technical University, Department of Econometrics, Kanuni Campus 61000 Trabzon, Turkey. Scientific affiliation: mathematical models, heuristic-metaheuristic search, decision-making. Phone: +090 46237730 00. Fax: +090 46232532 05. E-mail: ayan@ktu.edu.tr.

2 PhD, Bayburt University, Department of Business Administration, Dede Korkut Campus 69000 Bayburt, Turkey. Scientific affiliation: machine learning, fuzzy logic, time series analysis. Phone: +09045821111 74. Fax:+0904582111173.E-mail: hpabuccu@bayburt.edu.tr. (corresponding author).
} 


\section{Introduction}

Recently, the effect of knowledge on total factor productivity has been increased as well as the sustainable economic development. The use and the production of knowledge is very important for long-term and sustainable economic growth. At this point, an economy in which knowledge is the cornerstone of economic growth emerges and the concept of knowledge economy gains importance. The knowledge economy is a holistic approach that encompasses elements such as education, training, innovation, technological adaptation, appropriate economic incentive and institutional regime. The knowledge economy is a system in the center of which there is creation, dissemination and use of knowledge. Knowledge leads to innovation and technical changes, and becomes the driving force of an economy by increasing the productivity of production factors and the effectiveness of the production and dissemination process. Economies of developed countries are largely based on knowledge, and these countries spend a significant portion of their gross domestic product (GDP) for the production and dissemination of knowledge.

In recent years knowledge has become a fundamental production factor and has taken its place in the production function, because economic-developmentlevel of countries is henceforth determined by whether they produce and export high technology products or not. In today's highly competitive environment, evaluating the knowledge-based economic performance of countries has gained greater importance. This evaluation can be very beneficial both to see the current situation and to determine a path for countries with poor performance. An economy is constantly transformed into a knowledge economy with the production of knowledge and the active use of it.

It is clear that a successful transition to the knowledge economy depends on long-term investments in education, innovation development, modernizing the knowledge infrastructure and a suitable economic environment. The World Bank also called the mentioned determinants as the foundations of the knowledge economy. They have compiled the knowledge economy index they have calculated for countries on these determinants.

The aim of this study is to compare the effectiveness of the knowledge economy of the EU countries including Turkey. In this study, 2016 data collected from the World Bank's database were used and it was investigated whether the resources of the knowledge economy were used effectively by the countries. In all analyses, we focus on producing maximum output with fixed inputs by adopting the constant returns to scale. After determining the countries that are efficient on different levels, we rank these countries by determining their attractiveness scores. We also rank inefficient countries according to their progress scores and determine target values with both standard DEA and factor-specific DEA. 
The remainder of this paper is organized into six sections. Section 2 presents a brief overview of the related literature. Section 3 provides models used in this study. Section 4 provides empirical data and analysis. Section 5 presents results and discussion and the conclusions are presented in section 6 .

\section{Literature review}

There is a very important study based on econometric analysis applied by the World Bank (1999) to illustrate the role of knowledge in the development process of Ghana and the Republic of Korea. Hard to estimate, but it is true that two-thirds of the differences between the two countries are not due to the accumulation of physical capital and labor, rather they are due to other sources of growth and productivity, where knowledge is of high importance (World Bank Institute, 2007).

Adler, (2001), in his study where he makes inferences about the future of the knowledge economy and capitalism, emphasizes that the importance of knowledge is increasing on economies, the trend is towards knowledge-based economies, and high-reliability institutional structures will emerge as a result of these. Powell and Snellman, (2004) define the knowledge economy as an economy built on knowledge-intensive activities that accelerate technical and scientific development. Moreover, the conclusion that basic components of knowledge economy depend on the intellectual knowledge rather than accumulation of physical inputs or natural sources has been reached by the analysis where patent data are used. Roman, (2010) states that research and development activities are crucial for transition countries and that technological development is one of the basic elements of economic growth. In the study, regional efficiencies of Bulgaria and Romania were analyzed in 2003-2005. Henderman and Tjakraatmadja, (2012) emphasize that neoclassical economics have focused on the labor and capital factors for the last two centuries, but nowadays wealth-generating assets are knowledge and informationderived factors. They state that technology, knowledge and innovation are key factors in production. In the study, they try to model the relationship between knowledge-economy-workers' hard, soft skills; and innovativeness in one of the developing countries, Indonesia. Asongu, (2013), in his study on South Saharan Africa (SSA), Middle East and North Africa (MENA) countries, makes some inferences about the future of countries by using the four pillars of knowledge economy index (KEI) (economic incentive and institutional regime, education and human resources, innovation system and Information and communication technology). In the findings, it is emphasized that the countries with a low score of the knowledge economy are 4-7.5 years behind those with high scores. Luthi et al., (2013) form a conceptual framework for knowledge economy, and then experimentally investigates the functional urban hierarchy of Germany based on the relation of knowledge economy and geography. Munich, Rhine-Main, Hamburg, 
Rhine-Ruhr, Stuttgart and Berlin are selected as the strategic nodes of knowledge economy in the study. Mehra et al., (2014) emphasize that the role of education in the development of knowledge firms' productivity has not been examined. By using sub-components of KEI, Asongu, (2015) studies how competition in the financial sector affects the development of knowledge economy, and Tchamyou, (2016) does a study to assess the effect of the KEI in African business.

Data envelopment analysis is used to measure the effectiveness of DMUs in macroeconomic analysis as well as microeconomic studies. It will be useful to examine these studies in order to measure the effectiveness of the knowledge economy of countries. In Guan et. al, (2003), it is emphasized that researchers and managers have explored appropriate methods to explore the relationship between technological innovation capability and competitiveness. This study tries to find a systematic quantitative methodology to solve this problem. In a survey of 182 industrial innovation firms in China, the traditional DEA model was used to analyze the obtained data. Research results show that only $16 \%$ of enterprises operate at the best practices limit and there are some inconsistencies between organizational innovation capacity and competitiveness of many businesses. Halkos and Tzeremes (2007) discuss the importance of information and communication technologies (ICT) in global competition and its contribution to the national economy. The competitive structure of information and communication technologies has been investigated. The global strategies of the multinational ICT companies in the top 50 are examined. ICT activities of these companies were investigated by using DEA. The results show that there is a higher competition between competitors in communication and electronic-equipment segments. Tan and Hooy, (2007) measure the knowledge-based development performance of nine developed and developing countries. Five developed and four developing countries have been selected from different geographical regions. The performances of countries have been analyzed with Radar diagrams and DEA. Besides, Tan et al., (2008) evaluate the relative efficiency of 12 selected Asia-Pacific countries in terms of development of knowledge-based economy. Wu, (2011) discussed how to enrich the global competitiveness of tourism destinations and investigated the effectiveness of the countries. They suggested a new model based on DEA, Grey System theory and neural network with the idea that the rankings of reputable institutions could include calculation errors or human judgments. According to Charles and Zegarra, (2014), competitiveness has a positive effect on long-term economic growth. In order to help policy makers, the business world and academic community in Peru, competitiveness is measured and sorted by region. The study emphasizes that the DEA has not been used before in measuring regional competitiveness. The results showed that coastal regions are very competitive compared to the mountains and forest regions. Leyden and Link, (2014) express in the study in which they compare the research efficiency of government research labs with university research labs that intellectual-based institutions contribute greatly to economic development 
(in any economy). In Šegota (2017), it was emphasized that there is still no more unique method for measuring competitiveness, and that countries cannot use existing inputs efficiently due to some structural constraints in the economy. From this point of view, competitiveness activities of countries were measured by DEA. According to the results of the study, it is found that the traditional competitiveness indicators are incomplete because they do not take into account the macroeconomic efficiency of the country. Stanković and Radenković (2017) construct a link between the level of fulfillment of the criteria in the process of certification of cities and municipalities. The study presents the current way of conducting the procedure of certification of cities and municipalities, and based on the results of the correlation analysis and DEA method an insufficient effect on the fulfillment of these criteria to attract and activate investments at the local level was found.

In addition to the studies mentioned above, we try to examine the relative efficiency of European Union countries and Turkey in terms of the knowledge economy. The examination of efficiency results from an approach based on the theory of production functions. For efficiency measurement, there are two basic approaches: parametric frontier and Data Envelopment Analysis (DEA) (Gutiérrez-Nieto et al., 2007). In our study, we use the concept of efficiency to mean how high the output of knowledge economy is compared to the facilities the country has. We choose context dependent DEA and factor-specific DEA versions of DEA to measure efficiency. DEA is a nonparametric approach to measure the relative efficiency of DMUs while there has been multiple inputs and outputs (Charnes et al., 1978). The most powerful feature of DEA is to evaluate the DMUs relatively with respect to multiple input outputs (Jenkins and Anderson, 2003). DEA separates the DMUs into two groups as 'efficient' and 'inefficient'. Any DMUs efficiency score could be any real value between $0-1$.

Context dependent DEA proposed by (Seiford and Zhu, 2003) gives us the opportunity to evaluate each country within its own group as well as against other groups by dividing the countries into different efficiency levels. There are many studies related with context dependent DEA such as (Izadikhah, 2011; Lotfi and Esmaeili, 2008; Lotfi et al., 2012; Seiford and Zhu, 2003; Ulucan and Barış Atici, 2010).

When we look at the studies in the literature, while increasing efficiency, it may not be possible to make improvements in all inputs or outputs at the same time. In such cases, a single output (or input) can be improved to achieve efficiency. Factor-specific DEA is an excellent tool to determine the amount of improvement needed to be made individually in each input or output. The main hypothesis of the research is to determine the efficiency of the OECD countries' knowledge economy policy based on selected indicators. 


\section{Methodology}

\subsection{Context dependent DEA}

Data Envelopment Analysis (DEA) is a non-parametric analysis method to evaluate the relative efficiency of decision making units (DMUs) which are comparable organizational decision units with a lot of inputs and outputs (Charnes et al., 1978). DEA creates an efficient frontier to evaluate DMUs. DMUs on the frontier are called efficient and the ones below it are called inefficient. DEA also calculates efficiency scores for all DMUs that can range from 0 to 1 . The efficiency score of any DMU indicates its status with respect to the most efficient DMUs.

Any DEA model assumes either a constant return to scale (CRS) or a variable return to scale (VRS). In the case of VRS, interpretations are much more complex than CRS. Therefore, whereas CRS assumption are widely used, VRS are used only when it is necessary to control, in particular, increasing or decreasing returns (Kao and Liu, 2011).

The relative attractiveness of a DMU with respect to another DMU also depends on alternative DMUs. In other words, the relative attractiveness depends on the evaluation context constructed from alternative DMUs. Seiford and Zhu, (2003) developed context-dependent DEA based on it.

Context dependent DEA consists of two stages: the construction of efficient frontiers, and then the calculation of attractiveness and progress scores. At the first stage, $\mathrm{n}$ different efficient frontiers are created taking into account only inefficient DMUs at each step. The efficient frontier created with all DMUs is the highest one and it is called the first-level frontier. The lastly created one is the lowest and it is called $\mathrm{n}^{\text {th }}$ level efficient frontier. At the second stage, for each DMU, attractiveness scores with respect to the efficient frontiers below and progress scores with respect to the efficient frontiers above are calculated. Context-dependent DEA enables us to differentiate between DMUs which seems at the equal performance level and it provides more detailed information than the standard DEA. Besides, it suggests accessible targets of improvement for the inefficient DMUs and helps to achieve them step by step. The output oriented context dependent model presented in Seiford and Zhu, (2003) which is a linear programming problem can be summarized as follows:

We assume that each of $n$ DMUs has $m$ inputs $\left(\mathrm{x}_{\mathrm{ij}}\right)$ and $\mathrm{s}$ outputs $\left(\mathrm{y}_{\mathrm{kj}}\right)$. To obtain an efficiency score of each inefficient $\mathrm{DMU}_{0}$, the following CRS model is solved with another inefficient DMUs to obtain efficient frontiers. 
$\max \phi$

subject to:

$$
\begin{aligned}
& -\sum_{j=1}^{n} y_{k j} \lambda_{j}+y_{k 0} \phi \leq 0 ; \quad k=1, \ldots, s \\
& \sum_{j=1}^{n} x_{i j} \lambda_{j} \leq x_{i 0} ; \quad i=1, \ldots, m \\
& \lambda_{j} \geq 0 ; \quad j=1, \ldots, n
\end{aligned}
$$

Initially, all DMUs are considered as inefficient and model 1 becomes the original output oriented DEA. Then, the model is solved again the remaining DMUs by excluding efficient DMUs. It goes on until there is only one DMU left. At the end of this, a number of efficient frontiers are obtained -one for each step-. Each of these efficient frontiers forms a different evaluation context. Following this, attractiveness and progress scores are calculated for every DMU according to these contexts.

Figure 1: The measurement of attractiveness and progress in the context-dependent DEA model

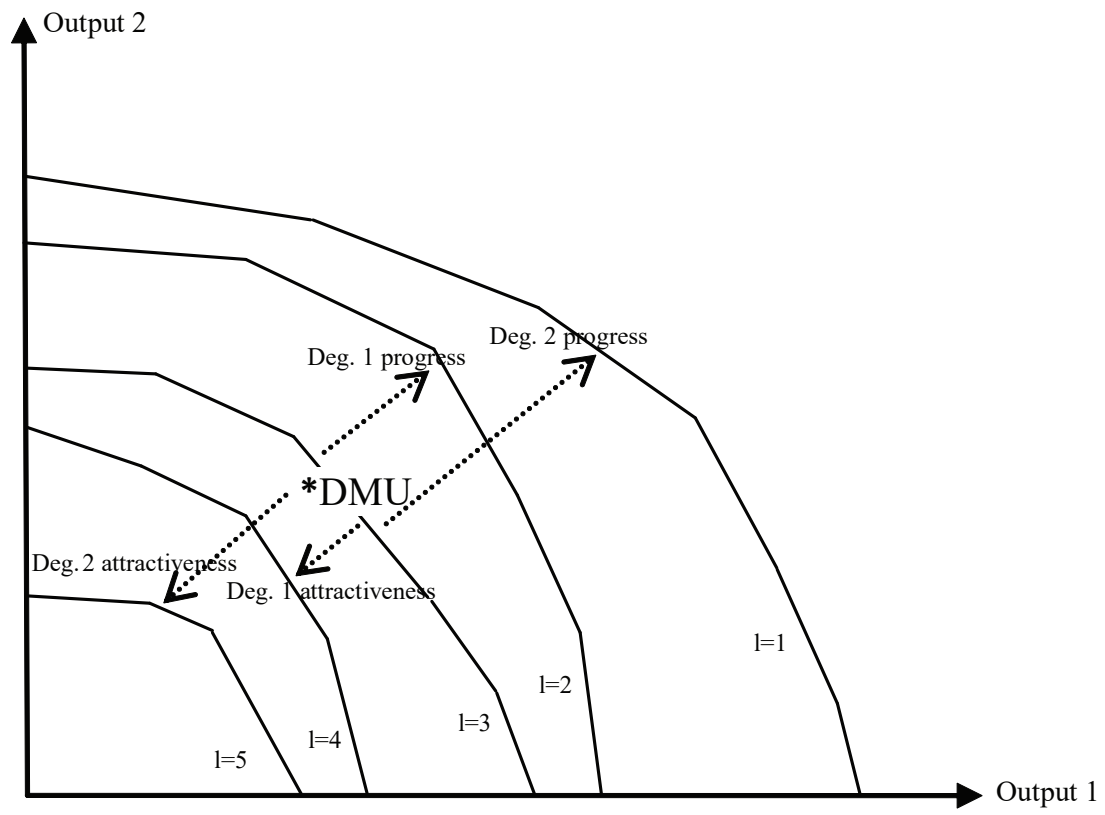

Source: Authors' calculations 
Any DMU should be evaluated against an efficient frontier at a lower level to obtain a relative attractiveness measure. To do this, model 1 should be solved with the DMU itself and DMUs efficient on a lower level frontier. The reciprocal of the optimal solution gives the attractiveness value. If there is more than one efficient frontier under a DMU, separate attractiveness scores for different-level efficient frontiers are calculated. It can be summarized as follows: The attractiveness score of a DMU on the $\mathrm{k}^{\text {th }}$ efficient frontier with respect to the $1^{\text {th }}$ level efficient frontier is called (1-k) ${ }^{\text {th }}$ level attractiveness value. Higher attractiveness scores are preferred as this is the measure of a DMU's radial distance to any of the efficient frontier with relatively poor performance.

Another measure in Context dependent DEA is progress score. The progress score of any DMU shows the amount of improvement that it needs to go up to a higher level. This value is the optimal solution of model 1 with the DMU itself and DMUs efficient on a higher level. The progress score of a DMU on $\mathrm{k}^{\text {th }}$ level efficient frontier with respect to the $1^{\text {th }}$ level efficient frontier is called $(1-k)^{\text {th }}$ level progress value $(\mathrm{k}<1)$. Smaller values are preferred since this score is the indicative of radial distance of any DMU to any efficient frontier with relatively high performance. In Fig. 1, the concept of attractiveness and progress is visualized for $\mathrm{DMU}_{0}$ which in on the $3^{\text {th }}$ efficiency level.

\subsection{Factor-Specific DEA}

In addition to efficiency scores, target values for inputs and outputs are determined to turn inefficient DMUs into efficient DMUs in DEA. It is recommended that all outputs are radially increased (or all inputs are radially reduced). However, in some cases it may not be possible to improve all outputs (inputs) at the same time. So the factor-specific DEA models that prioritize some outputs (inputs) may be more appropriate $(\mathrm{Zhu}, 2000)$. For output $\mathrm{y}_{\mathrm{f} 0}$ of inefficient $\mathrm{DMU}_{0}$ output oriented factorspecific CRS model:

$\max \phi$

subject to:

$$
\begin{aligned}
& -\sum_{j=1}^{n} y_{f j} \lambda_{j}+y_{f 0} \phi \leq 0 \\
& -\sum_{j=1}^{n} y_{k j} \lambda_{j}+y_{k 0} \leq 0 ; \quad k=1, \ldots, s ; k \neq f \\
& \sum_{j=1}^{n} x_{i j} \lambda_{j} \leq x_{i 0} ; \quad i=1, \ldots, m \\
& \lambda_{j} \geq 0 ; \quad j=1, \ldots, n
\end{aligned}
$$


There is an input-specific version of the model (2) in Thanassoulis and Dyson, (1992). Model 2 can be solved with inefficient DMUs at each stage to obtain different evaluation contexts. Thus, more detailed and more realistic interpretations can be made.

\section{Empirical data and analysis}

We aimed to include all European countries in our study. However, due to the lack of data, we could not include Luxemburg, Slovakia, Slovenia, Poland, and Portugal. We have included 22 European Union countries and Turkey in the study. While selecting the variables (input and output), we have tried to determine commonly used and the most effective variables. The selected variables are related with the most important pillars affecting the knowledge economy as presented in World Bank Knowledge Assessment Methodology (KAM), (Chen and Dahlman, 2005). We have chosen human development index (HDI), research and development expenditure as rate of GDP (RD), growth rate of GDP (GDPGRWTH) as inputs, and number of mobile communication subscriptions and penetration per 100 inhabitants (MBCOM), exports of high technology products as a share of total exports (EXPHTECH), number of internet host per 100 inhabitants (INTUSERS), patent applications (PATENT) as outputs. HDI is an index created by the World Bank to assess the level of development of a country, not only economic growth. It has three dimensions: having long and healthy life, proper standard of living condition and being knowledgeable. It is geometric mean of normalized indices of these three dimensions (http://hdr. undp.org/en 13.02.2017). A patent application is an indicator of the creation of new technologies granted by the United States Patent and Trademark Office (USPTO). In the study, we use output-oriented DEA models as our main goal is to maximize the outputs. We use Context dependent DEA and factor-specific DEA to identify realistic targets for inefficient countries and to improve them step by step. We use DEA Excel Solver and Excel Solver for analysis. The 2016 data on the inputs and outputs were obtained from the World Bank's databank. Descriptive statistics for input and output variables are as follows in Table 1.

Table 1: Descriptive statistics

\begin{tabular}{|c|c|c|c|c|c|c|c|}
\hline & MBCOM & EXPHTECH & INTUSERS & PATENT & HDI & RD & GDPGRWTH \\
\hline Minimum & 95,400 & 2,160 & 54 & 5 & 0,761 & 0,460 & 1,1 \\
\hline Maximum & 157,410 & 34,460 & 96 & 17752 & 0,923 & 3,260 & 4,3 \\
\hline Mean & 121,936 & 14,387 & 79,130 & 2085,957 & 0,866 & 1,703 & 2,274 \\
\hline Std dev. & 17,462 & 7,621 & 11,482 & 3984,089 & 0,044 & 0,870 & 1,016 \\
\hline
\end{tabular}

Source: Authors' calculations 
With context-dependent DEA, countries are divided into three levels of efficiency. Table 2 presents the results of the first level context dependent DEA, which is the same as the standard DEA. As it is seen, 14 of 23 countries are efficient $(\mathrm{e}=1)$. The efficiency scores show the efficiency of the countries with respect to the most efficient country.

Table 2: Efficiency scores and output targets in context dependent DEA first level

\begin{tabular}{|c|c|c|c|c|c|c|c|c|c|}
\hline \multirow[b]{2}{*}{ Country } & \multirow{2}{*}{$\begin{array}{c}\text { Efficiency } \\
\text { Score }\end{array}$} & \multicolumn{2}{|c|}{ MBCOM } & \multicolumn{2}{|c|}{ ЕХРНТЕСН } & \multicolumn{2}{|c|}{ INTUSERS } & \multicolumn{2}{|c|}{ PATENT } \\
\hline & & $\begin{array}{c}\text { Present } \\
\text { quantity }\end{array}$ & Target & $\begin{array}{l}\text { Present } \\
\text { quantity }\end{array}$ & Target & $\begin{array}{l}\text { Present } \\
\text { quantity }\end{array}$ & Target & $\begin{array}{l}\text { Present } \\
\text { quantity }\end{array}$ & Target \\
\hline Austria & 1 & 157,41 & - & 13,97 & - & 84,00 & - & 1262 & - \\
\hline Belgium & 0,9258 & 115,69 & 127,94 & 12,96 & 13,99 & 85,00 & 91,75 & 1225 & 2076,92 \\
\hline Bulgaria & 1 & 129,27 & - & 7,65 & - & 57,00 & - & 34 & - \\
\hline Croatia & 0,9842 & 103,76 & 105,57 & 8,96 & 12,71 & 71,00 & 72,21 & 14 & 805,11 \\
\hline Cyprus & 1 & 95,40 & - & 6,15 & - & 72,00 & - & 10 & \\
\hline Czech & 0,9361 & 129,21 & 137,96 & 14,52 & 18,09 & 81,00 & 86,49 & 206 & 713,35 \\
\hline Denmark & 1 & 128,34 & - & 17,92 & - & 96,00 & - & 1190 & - \\
\hline Estonia & 1 & 148,68 & - & 11,39 & - & 88,00 & - & 43 & - \\
\hline Finland & 1 & 135,50 & - & 8,73 & - & 93,00 & - & 1485 & - \\
\hline France & 1 & 102,61 & - & 28,45 & - & 85,00 & - & 7026 & - \\
\hline Germany & 1 & 113,71 & - & 16,66 & - & 88,00 & - & 17752 & - \\
\hline Greece & 0,8326 & 113,98 & 137,00 & 11,00 & 29,89 & 67,00 & 80,51 & 77 & 91,93 \\
\hline Hungary & 0,9103 & 118,91 & 130,57 & 13,74 & 24,28 & 72,00 & 79,07 & 158 & 367,12 \\
\hline Ireland & 0,9232 & 103,70 & 133,53 & 25,83 & 27,98 & 82,00 & 88,83 & 515 & 2798,97 \\
\hline Italy & 1 & 151,32 & - & 7,34 & - & 66,00 & - & 3090 & - \\
\hline Latvia & 1 & 104,64 & - & 14,95 & - & 79,00 & - & 5 & - \\
\hline Lithuania & 1 & 139,52 & - & 11,86 & - & 71,00 & - & 13 & - \\
\hline Malta & 1 & 129,30 & - & 34,46 & - & 76,00 & - & 7 & - \\
\hline Netherlands & 1 & 123,54 & - & 19,99 & - & 93,00 & - & 2788 & - \\
\hline Spain & 0,9399 & 107,89 & 114,83 & 7,15 & 17,25 & 78,00 & 83,01 & 912 & 3158,56 \\
\hline Sweden & 0,9607 & 130,38 & 135,68 & 14,25 & 14,83 & 90,00 & 93,66 & 2862 & 2980,54 \\
\hline Turkey & 0,7603 & 96,02 & 126,30 & 2,16 & 16,06 & 54,00 & 71,03 & 136 & 178,38 \\
\hline UK & 1 & 125,75 & - & 20,80 & - & 92,00 & - & 7167 & - \\
\hline
\end{tabular}

Source: Authors' calculations

Table 2 also shows target values for each of the nine inefficient countries. The target values indicate the quantities of outputs that the relevant country must produce so that its efficiency score reaches to 1, ceteris paribus. For example, in order to be efficient with regard to other 22 countries, Turkey has to increase mobile phone subscriptions 
by $31.53 \%$, exports of high technology products by $643.49 \%$, number of internet hosts by $31.53 \%$ and patent applications by $31.16 \%{ }^{5}$. Should Turkey make all these improvements, ceteris paribus, it would be among the efficient countries.

Figure 2: Efficiency scores in context dependent DEA level 1

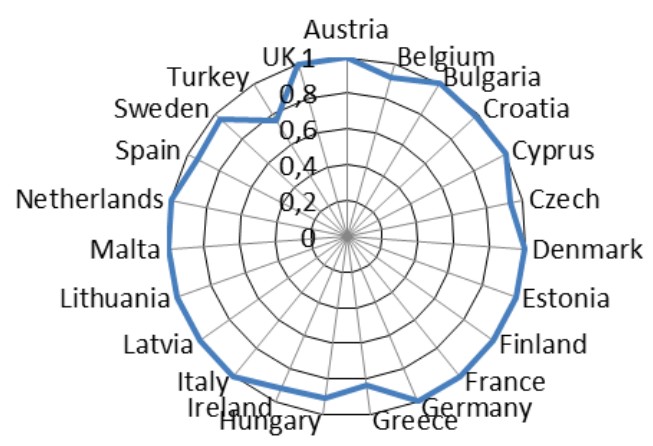

Source: Authors' calculations

The spider diagram in Figure 2 shows the knowledge economy performances of all 23 countries while the diagram in Figure 3 shows the relative performances of countries which are inefficient at the first level. The outermost countries in the spider diagram are the ones that are the most efficient ones i.e., the ones constructing efficient frontier. Input minimization will give the same results, however; we focus on output maximization in the study, so these countries can be defined as the ones producing the best outputs with regard to their facilities.

Figure 3: Efficiency scores in context dependent DEA level 2

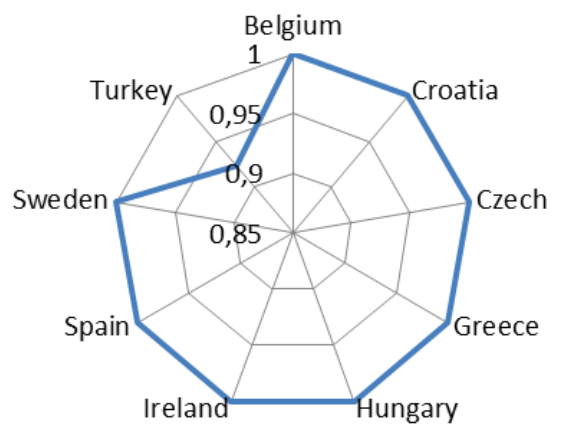

Source: Authors' calculations

$\overline{5(178.38-136) / 136}=0.3116$ 
According to the second level Context dependent DEA results in Table 3, only Turkey is found inefficient. So the third stratum consists of only Turkey.

Table 3: Efficiency scores and output targets in context dependent DEA second level

\begin{tabular}{|l|r|r|r|r|r|r|r|r|r|}
\hline \multirow{2}{*}{ Country } & \multirow{2}{*}{$\begin{array}{c}\text { Efficiency } \\
\text { Score }\end{array}$} & \multicolumn{2}{|c|}{$\begin{array}{c}\text { MBCOM } \\
\text { quantity }\end{array}$} & \multicolumn{2}{|c|}{ EXPHTECH } & \multicolumn{2}{c|}{ INTUSERS } & \multicolumn{2}{c|}{ PATENT } \\
\hline Belgium & 1 & 115,69 & - & $\begin{array}{c}\text { Present } \\
\text { quantity }\end{array}$ & Target & $\begin{array}{c}\text { Present } \\
\text { quantity }\end{array}$ & Target & $\begin{array}{c}\text { Present } \\
\text { quantity }\end{array}$ & Target \\
\hline Croatia & 1 & 103,76 & - & 8,96 & - & 71,00 & - & 14 & - \\
\hline Czech & 1 & 129,21 & - & 14,52 & - & 81,00 & - & 206 & - \\
\hline Greece & 1 & 113,98 & - & 11,00 & - & 67,00 & - & 77 & - \\
\hline Hungary & 1 & 118,91 & - & 13,74 & - & 72,00 & - & 158 & - \\
\hline Ireland & 1 & 103,70 & - & 25,83 & - & 82,00 & - & 515 & - \\
\hline Spain & 1 & 107,89 & - & 7,15 & - & 78,00 & - & 912 & - \\
\hline Sweden & 1 & 130,38 & - & 14,25 & - & 90,00 & - & 2862 & - \\
\hline Turkey & 0,9234 & 96,02 & 103,988 & 2,16 & 10,8779 & 54,00 & 62,1177 & 136 & 147,286 \\
\hline
\end{tabular}

Source: Authors' calculations

According to Table 3, Turkey needs to increase mobile phone subscriptions by $8.30 \%$, exports of high technology products by $403.61 \%$, the number of internet hosts by $15.14 \%$ and patent applications by $8.30 \%$ together in order to be efficient compared to the 7 countries in the first column, -that is; to reach a higher level even if not being fully efficient.

Table 4 presents the attractiveness and progress scores calculated to differentiate the countries that are efficient at the same level for a more realistic evaluation. The fourth column in Table 4 shows the second-level attractiveness scores of the countries which are efficient in level 1. It also shows first level attractiveness scores of the countries that are efficient in level 2. The fifth column shows first level progress scores of the countries that are efficient in level 2, and the second level progress score of Turkey which is the only country efficient in level 3 . The third column shows first level attractiveness scores of the countries that are efficient at first level, and the last column shows only the second level progress score of Turkey. As mentioned before, high attractiveness scores and low progress scores are preferred. 
Tuba Yakıcı Ayan, Hakan Pabuçcu • The assessment of knowledge economy efficiency...

Table 4: Attractiveness and progress scores for the DMUs

\begin{tabular}{|c|c|c|c|c|c|}
\hline \multirow{3}{*}{ Country } & \multirow{3}{*}{$\begin{array}{l}\text { Efficiency } \\
\text { Level }\end{array}$} & \multicolumn{2}{|c|}{ Attractiveness } & \multicolumn{2}{|c|}{ Progress } \\
\hline & & \multicolumn{2}{|c|}{ Evaluation context } & \multicolumn{2}{|c|}{ Evaluation context } \\
\hline & & Level2 & Level3 & Level1 & Level2 \\
\hline Austria & 1 & 1,2975 & 22,1675 & - & - \\
\hline Bulgaria & 1 & 1,2451 & 8,4601 & - & - \\
\hline Cyprus & 1 & 1,8738 & 11,1300 & - & - \\
\hline Denmark & 1 & 1,1019 & 20,9028 & - & - \\
\hline Estonia & 1 & 1,1971 & 5,8140 & - & - \\
\hline Finland & 1 & 1,1608 & 29,3451 & - & - \\
\hline France & 1 & 4,8949 & 130,6739 & - & - \\
\hline Germany & 1 & 10,9709 & 295,4087 & - & - \\
\hline Italy & 1 & 3,1021 & 81,4154 & - & - \\
\hline Latvia & 1 & 1,7965 & 11,5355 & - & - \\
\hline Lithuania & 1 & 1,2361 & 6,0539 & - & - \\
\hline Malta & 1 & 2,7029 & 34,3005 & - & - \\
\hline Netherlands & 1 & 2,6713 & 73,4583 & - & - \\
\hline UK & 1 & 4,8021 & 94,4182 & - & - \\
\hline Belgium & 2 & 1 & 27,6654 & 1,0801 & - \\
\hline Croatia & 2 & 1 & 14,8642 & 1,0160 & - \\
\hline Czech & 2 & 1 & 13,1389 & 1,0683 & - \\
\hline Greece & 2 & 1 & 7,5511 & 1,2010 & - \\
\hline Hungary & 2 & 1 & 13,0251 & 1,0985 & - \\
\hline Ireland & 2 & 1 & 20,5683 & 1,0760 & - \\
\hline Spain & 2 & 1 & 16,9619 & 1,0639 & - \\
\hline Sweden & 2 & 1 & 25,8414 & 1,0409 & - \\
\hline Turkey & 3 & - & 1 & 1,3153 & 1,0829 \\
\hline
\end{tabular}

Source: Authors' calculations

Countries which are efficient in level 1 are ranked as Germany, France, United Kingdom, Italy, Malta, Netherlands, Cyprus, Latvia, Austria, Bulgaria, Lithuania, Estonia, Finland and Denmark according to their first level attractiveness scores. Germany ranks first with an attractiveness score of (10.97) more than twice as high as of France in the second place (4.89). United Kingdom (4.80) and Italy (3.10) are other top countries in terms of first level attractiveness scores. The rest of the countries have very close scores. When countries efficient in level 1 are ranked according to their second-level attractiveness scores, the list is as follows: Germany, France, United Kingdom, Italy, Netherlands, Malta, Finland, Austria, Denmark, Latvia, Cyprus, Bulgaria, Lithuania, and Estonia. Germany again stands out with a 
very high score and the first six countries are the same as the previous one. In fact, it should be kept in mind that these countries' second level attractiveness scores only refer to their performance with regard to Turkey.

As it can be seen in the fourth column of Table 4, efficient countries in level 2 ranked according to their attractiveness scores are: Belgium, Sweden, Ireland, Spain, Croatia, Czech Republic, Greece and Hungary. When countries efficient in level 2 are ranked according to their first level progress scores, the list from low to high becomes as follows: Croatia, Sweden, Spain, Czech Republic, Ireland, Belgium Hungary and Greece. As it is seen, Belgium is worse than a lot of countries in terms of its progress score, although it has the best attractiveness value in second- level -efficient countries, which means that it is quite difficult for the countries being on lower efficient frontiers to reach Belgium's level. Similarly, it is difficult for Belgium to reach a higher efficiency level. Hungary and Greece took the last two orders in terms of both scores. According to this finding, it can be said that it is difficult for Hungary and Greece to reach a higher level, although it is easy for lower level countries to reach their level. The best country in the second level is Sweden, which ranks second in terms of both scores; because it is difficult for lower-level countries to reach the level of Sweden, and it is easy for Sweden to reach higher levels.

Since it is more appropriate to set individual targets for each input or output in real life, we use factor-specific DEA in addition to standard DEA. Table 5 shows the efficiency scores obtained with factor-specific DEA, required improvement rates and target values for each output. When compared to the targets in Table 2, they are really different. For instance, Greece, which is efficient on the second level faces 5 options in terms of outputs in order to reach the first level (provided that inputs and outputs of other countries are fixed). The first option is to increase mobile communication subscription rates by $20 \%$, exports of high technology products by $172 \%$, rate of internet hosts by $20 \%$ and the number of patent applications by $19 \%$. The second option is to increase mobile phone subscriptions by $22.37 \%$, the third is to increase exports of high technology products by $222.27 \%$, the fourth is to increase internet hosts by $23.20 \%$ and the fifth option is to increase the number of patent applications by $3391.25 \%$. 
Tuba Yakıcı Ayan, Hakan Pabuçcu • The assessment of knowledge economy efficiency...

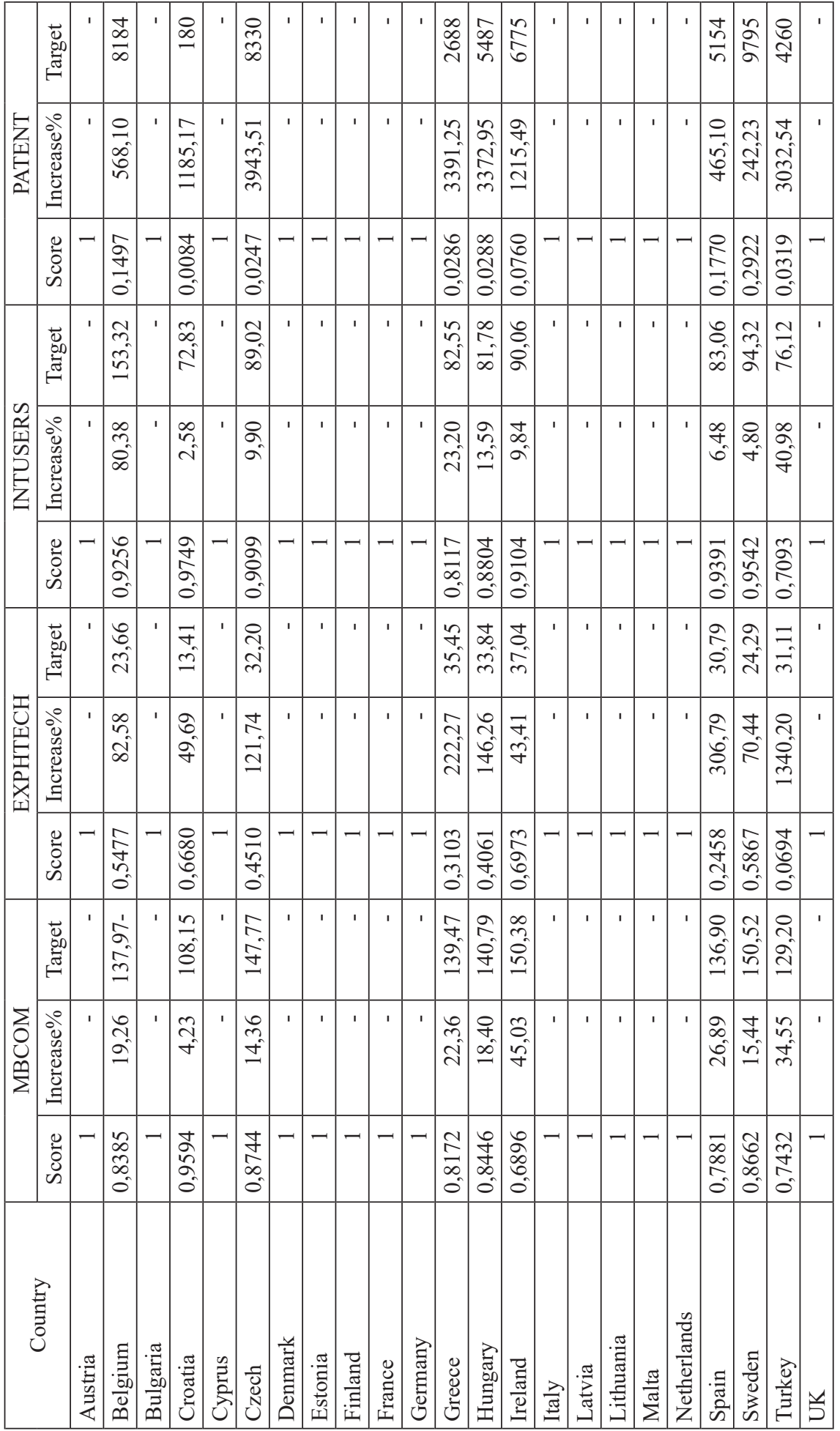

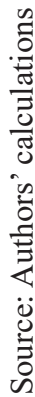


As it is shown in Table 5, in order to be efficient with respect to other 22 countries, Turkey should increase mobile phone communication subscriptions by $34.55 \%$ or exports of high technology products by $1340.20 \%$ or rate of internet hosts by $40.98 \%$ or patent applications by $3032.54 \%$ as an alternative to improving all outputs together. Looking at the output targets in Table 5, it can be seen that the biggest improvement needed to be made is in patent applications. In other words, inefficient countries can be efficient by increasing their patent applications by an average of $1935.15 \%$. On the other hand, an improvement of only $21.30 \%$ on average is sufficient in internet hosts rate. Based on this, it can be said that the lowest output of inefficient countries with regard to efficient countries is patent applications and they need to increase it about 20 times.

The improvement that Turkey needs to make at each output to reach a higher level even if not to be fully efficient- is shown in Table 6 .

Table 6: Factor-specific efficiency scores and output improvements (level 2)

\begin{tabular}{|c|c|c|c|c|c|c|}
\hline \multirow[b]{2}{*}{ Country } & \multicolumn{3}{|c|}{ MBCOM } & \multicolumn{3}{|c|}{ EXРНTЕCH } \\
\hline & Score & $\begin{array}{c}\text { Increase } \\
\%\end{array}$ & Target & Score & $\begin{array}{c}\text { Increase } \\
\%\end{array}$ & Target \\
\hline Belgium & 1 & - & - & 1 & - & - \\
\hline Croatia & 1 & - & - & 1 & - & - \\
\hline Czech & 1 & - & - & 1 & - & - \\
\hline Greece & 1 & - & - & 1 & - & - \\
\hline Hungary & 1 & - & - & 1 & - & - \\
\hline Ireland & 1 & - & - & 1 & - & - \\
\hline Spain & 1 & - & - & 1 & - & - \\
\hline Sweden & 1 & - & - & 1 & - & - \\
\hline Turkey & 0,9218 & 8,48 & 104,17 & 0,1516 & 559,63 & 14,25 \\
\hline \multirow[b]{2}{*}{ Country } & \multicolumn{3}{|c|}{ INTUSERS } & \multicolumn{3}{|c|}{ PATENT } \\
\hline & Score & $\begin{array}{c}\text { Increase } \\
\%\end{array}$ & Target & Score & $\begin{array}{c}\text { Increase } \\
\% \\
\end{array}$ & Target \\
\hline Belgium & 1 & - & - & 1 & - & - \\
\hline Croatia & 1 & - & - & 1 & - & - \\
\hline Czech & 1 & - & - & 1 & - & - \\
\hline Greece & 1 & - & - & 1 & - & - \\
\hline Hungary & 1 & - & - & 1 & - & - \\
\hline Ireland & 1 & - & - & 1 & - & - \\
\hline Spain & 1 & - & - & 1 & - & - \\
\hline Sweden & 1 & - & - & 1 & - & - \\
\hline Turkey & 0,8007 & 24,89 & 67,44 & 0,2130 & 369,48 & 638 \\
\hline
\end{tabular}

Source: Authors' calculations 
According to Table 6, they are $8.48 \%$ for mobile communication subscriptions; $559.63 \%$ for exports of high technology products; $24.89 \%$ for internet hosts or $369.48 \%$ for patent applications.

Figure 4: Output specific efficiency scores
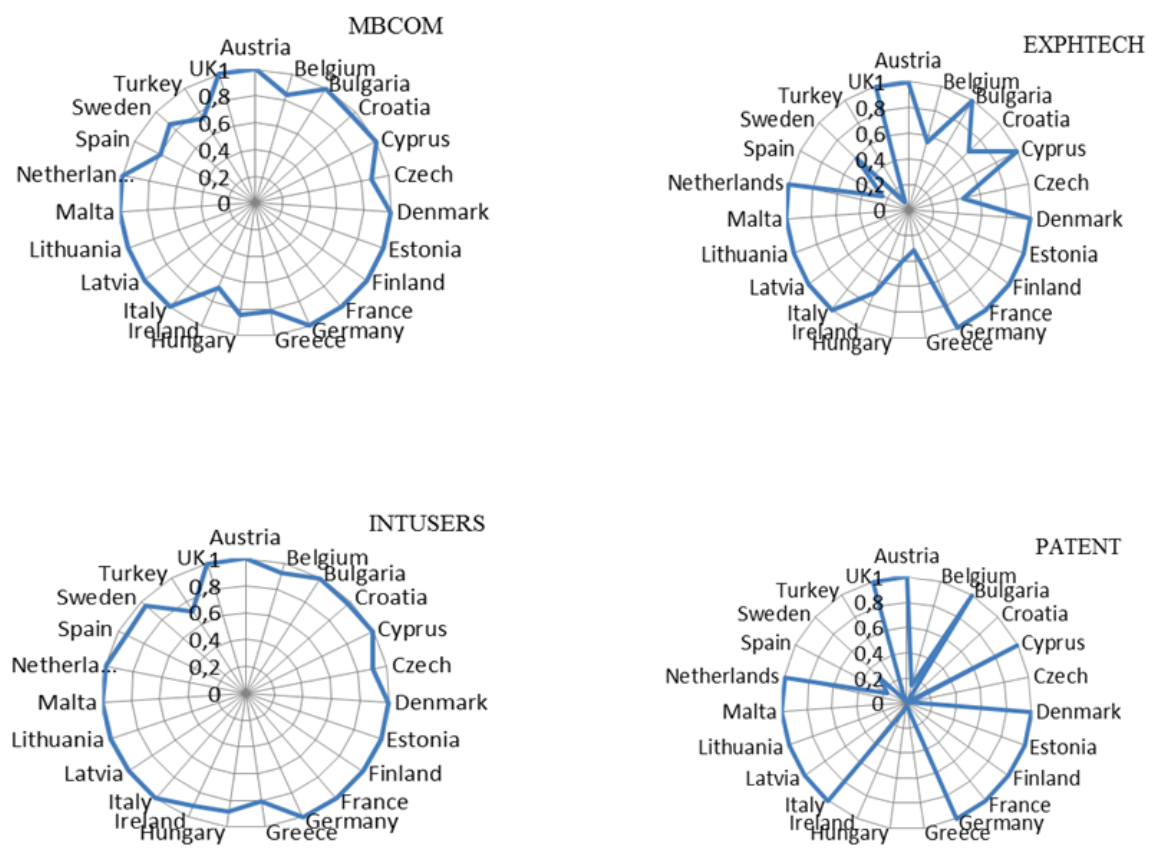

Source: Authors' calculations

Figure 4 shows the efficiency scores of countries related with each output and the variation in these scores. As it is clear, countries have very different performances in terms of patent applications compared to the facilities. Variation is also high in terms of exports of high technology products. However, with regard to other outputs, countries have higher efficiency scores and show similar performances.

\section{Results and discussion}

In this study, we have investigated the applicability of context- dependent and factor-specific DEA approaches in European countries to evaluate the efficiency of the knowledge economy performance. Applications are conducted using data consisting of 23 DMUs representing the countries of the European Union and Turkey. Four inputs and three outputs are determined according to knowledge assessment methodology of the World Bank. Output-oriented DEA models are 
applied as our main goal is to maximize the outputs. Context dependent DEA and factor-specific DEA are used to identify realistic targets for inefficient countries and to improve them step by step.

The analysis applied in two steps: As a first step output oriented DEA methodologies are applied. As a result of the standard DEA, inefficient units and unrealistic targets for these inefficient DMUs obtained. The obtained results show the applicability of the context dependent and factor specific DEA. The context dependent DEA applied to determine the efficiency level of the DMUs, and to identify the realistic targets. In the second step, factor- specific DEA methodology is applied. By using factor specific DEA models, target values via each input or output were obtained. Factor-specific DEA use is useful because it is possible to change results when different variables are used

Relative efficiency of 22 European countries and Turkey are evaluated in terms of the knowledge economy. We present current situation of the surveyed countries and set targets to improve them. The findings of this research are limited with the input and output variables used here. Since it examines the outputs, individually and independently of each other in factor-specific DEA, the state of any output does not change as long as the inputs remain the same. It gives us the opportunity to make comments that are more generalizable.

Efficiency is used to show the highest output of countries compared to their facilities, not necessarily their absolute maximum output. With this in mind, a country producing a lot of output may not be efficient, but a country with a little output can be efficient. Our analysis reveals that 14 out of 23 countries are efficient. In all analyses, Germany is clearly ahead of other countries. Germany is followed by France, England, Malta and the Netherlands. Turkey, on the other hand, is separated from other countries and is the least efficient one.

It can be misleading to interpret countries' efficiencies, according to their economic size in terms of the knowledge economy. For instance, Turkey is found to be inefficient in this study, although it ranks $22^{\text {nd }}$ in terms of economic size according to World Bank data 2016. However, Cyprus, Bulgaria, Lithuania and Latvia are found to be efficient, though they rank a lot lower. (http://data.worldbank.org/datacatalog/GDP- Ranking-table). The reason for this finding is that Turkey produces less output than expected relative to its facilities.

While setting targets for inefficient countries, it is noticed that patent application is the poorest output they have and it is followed by exports of high technology products. In this case, it is crucial to give special importance to these two outputs in order to be efficient in terms of the knowledge economy.

The results show that the efficiency evaluations with context-dependent and factorspecific DEA has an important role for DMUs in setting achievable targets or 
grouping of DMUs. Inside such a real world, achieving targets with each input and output reveals more realistic and achievable short-term target for the units.

\section{Conclusion}

This study measures whether countries use knowledge economy resources effectively. Countries that are unable to use resources effectively are offered improvements. In this study, the constant return assumption was preferred. In another study, under the assumption of variable return according to the scale, it is possible to investigate whether the countries have the optimum size in terms of their knowledge economy inputs. In this way, the question of what rate the increases in the inputs can increase the outputs can also be answered. It is possible to say that the conducted analysis results could change by using different data set and different variables. In addition to these adding or removing the decision making units could change the efficiency score. We planned to include rule of law variable at first as an input of the knowledge economy. However, we omitted it as it contains negative values. In fact, some methods are developed for standard DEA with negative values in the literature. However, the calculation of progressive and attractiveness scores with negative values and the application of factor-specific DEA can be the subject of future studies. Another aspect of our study that is amenable to improvement is to apply weighted DEA, especially for outputs. In order to determine the weights for that, Analytical Hierarch Process, Entropy or Fuzzy Logic methods can be used based on expert opinions. Finally, we could not find any paper to measure the relative efficiency of the countries' knowledge economy performance by using the DEA or else method.

\section{References}

Adler, P. S. (2001) "Market, Hierarchy, and Trust: The Knowledge Economy and the Future of Capitalism", Organization Science, Vol. 12, No. 2, pp. 215-234, doi: 10.1287/orsc.12.2.215.10117.

Asongu, S. A. (2013) "Modeling The Future Of Knowledge Economy: Evidence From SSA And MENA Countries", AGDI Working Paper, No. WP/13/015. Cameroon.

Asongu, S. A. (2015) "Financial Sector Competition and Knowledge Economy: Evidence from SSA and MENA Countries", Journal of the Knowledge Economy, Vol. 6, No. 4, pp. 717-748, doi: 10.1007/s13132-012-0141-4.

Charles, V., Zegarra, L. F. (2014) "Measuring regional competitiveness through Data Envelopment Analysis: A Peruvian case", Expert Systems with Applications. Elsevier Ltd, Vol. 41, No. 11, pp. 5371-5381, doi: 10.1016/j.eswa.2014.03.003. 
Charnes, A., Cooper W. W., Rhodes, E. (1978) "Measuring The Efficiency Of Decision Making Units", European Journal of Operational Research, Vol. 2, No. 6, pp. 429-444, doi: 10.1016/0377-2217(78)90138-8.

Chen, D. H. C., Dahlman, C. J. (2005) "The Knowledge Economy, the KAM Methodology and World Bank Operations (The Knowledge Economy)", The Knowledge Economy. Washington.

Guan, J. C., et al. (2006) "A study of the relationship between competitiveness and technological innovation capability based on DEA models", European Journal of Operational Research, Vol. 170, No. 3, pp. 971-986, doi: 10.1016/j.ejor. 2004.07.054.

Gutiérrez-Nieto, B., Serrano-Cinca C., Mar, M. C. (2007) “Microfinance Institutions And Efficiency", Omega, Vol. 35, No. 2, pp. 131-142, doi: 10.1016/j.omega. 2005.04.001.

Halkos, G. E., Tzeremes, N. G. (2007) "International competitiveness in the ICT industry: Evaluating the performance of the top 50 companies", Global Economic Review, Vol. 36, No. 2, pp. 167-182, doi: 10.1080/12265080701374115.

Hendarman, A. F., Tjakraatmadja, J. H. (2012) "Relationship among Soft Skills, Hard Skills, and Innovativeness of Knowledge Workers in the Knowledge Economy Era", Procedia - Social and Behavioral Sciences, Vol. 52, pp. 35-44, doi: 10.1016/j.sbspro.2012.09.439.

http://data.worldbank.org/data-catalog/GDP-ranking-table.

Izadikhah, M. (2011) "Context-Dependent Data Envelopment Analysis with Interval Data", American Journal of Computational Mathematics, Vol. 1, No. 4, pp. 256-263, doi: 10.4236/ajcm.2011.14031.

Jenkins, L., Anderson, M. (2003) “A Multivariate Statistical Approach To Reducing The Number Of Variables In Data Envelopment Analysis", European Journal of Operational Research, Vol. 147, pp. 51-61, doi: 10.1016/S0377-2217(02)00243-6.

Kao, C., Liu, S. T. (2011) Efficiencies of Two-Stage Systems with Fuzzy Data. Fuzzy Sets and Systems, Vol. 176, pp. 20-35, doi: 10.1016/j.fss.2011.03.003.

Leyden, D. P., Link, A. N. (2014) "Research Risk and Public Policy in a Knowledge-Based Economy: the Relative Research Efficiency of Government Versus University Labs", Journal of the Knowledge Economy, Vol. 5, No. 2, pp. 294-304, doi: 10.1007/s13132-012-0145-0.

Lotfi, F. H., Esmaeili, M. (2008) “On FDH Context-Dependent Data Envelopment Analysis, Mathematical Sciences, Vol. 2, No. 4, pp. 391-400.

Lotfi, F. H. et al. (2012) "Context-Dependent Data Envelopment AnalysisMeasuring Attractiveness and Progress with Interval Data", International Journal of Applied, Vol. 1, No. 3, pp. 71-90.

Luthi, S., Thierstein, A., Bentlage, M. (2013) "The Relational Geography Of The Knowledge Economy In Germany: On Functional Urban Hierarchies And 
Localised Value Chain Systems", Urban Studies, Vol. 50, No. 2, pp. 276-293, doi: $10.1177 / 0042098012452325$.

Mehra, A. et al. (2014) "Estimating Returns to Training in the Knowledge Economy: A Firm Level Analysis of Small and Medium Enterprises" MIS Quarterly, Vol. 38, No. 3, pp. 1-38, Available at SSRN: https://ssrn.com/abstract=2484499.

Powell, W. W., Snellman, K. (2004) “The Knowledge Economy”, Annual Review of Sociology, Vol. 30, No. 1, pp. 199-220, doi: 10.1146/annurev.soc.29.010202. 100037.

Roman, M. (2010) "Regional Efficiency Of Knowledge Economy In The New EU Countries: The Romanian And Bulgarian case", Munich Persona RePEc Archive, Romania. Retrieved from https://mpra.ub.uni-muenchen.de/23083.

Šegota, A., Tomljanović, M., Huđek, I. (2017) "Contemporary approaches to measuring competitiveness - the case of EU member states", Zbornik radova Ekonomskog fakulteta u Rijeci: časopis za ekonomsku teoriju i praksu/ Proceedings of Rijeka Faculty of Economics: Journal of Economics and Business, Vol. 35, No. 1, pp. 123-150, doi: 10.18045/zbefri.2017.1.123.

Seiford, L. M., Zhu, J. (2003) "Context-Dependent Data Envelopment Analysis Measuring Attractiveness And Progress", Omega-International Journal of Management Science, Vol. 31, No. 5, pp. 397-408, doi: 10.1016/S03050483(03)00080-X.

Stanković J., Radenković Jocić D. (2017) "The role of business environment in the promotion of investment activities: case study of cities and municipalities in the Republic of Serbia, Themes", Journal for Social Sciences, Vol. XLI, No. 2, pp. 457-473.

Tan, H. B., Hooy, C. W. (2007) "The Development Of East Asian Countries Towards A Knowledge-Based Economy: A DEA analysis", Journal of the Asia Pacific Economy, Vol. 12, No. 1, pp. 17-33, doi: 10.1080/13547860601083538.

Tan, H. B. et al. (2008) "Relative Efficiency Measures For The Knowledge Economies In The Asia Pacific Region", Journal of Modelling in Management, Vol. 3, No. 2, pp. 111-124, doi: 10.1108/17465660810890108.

Tchamyou, V. S. (2016) "The Role of Knowledge Economy in African Business", Journal of the Knowledge Economy, Vol.12, pp. 1-40, doi: 10.1007/s13132016-0417-1.

Ulucan, A., Barış Atıc1, K. (2010) "Efficiency Evaluations With Context-Dependent And Measure-Specific Data Envelopment Approaches: An application in a World Bank supported project", Omega, Vol. 38, No. 1, pp. 68-83, doi: 10.1016/j.omega.2009.04.003.

World Bank Institute, (2007) "Building Knowledge Economies: Advanced Strategies For Development", WBI Development Studies, retrieevd from: https://openknowledge.worldbank.org. 
Wu, W. W. (2011) "Beyond Travel \& Tourism competitiveness ranking using DEA, GST, ANN and Borda count", Expert Systems with Applications, Vol. 38, No. 10, pp. 12974-12982, doi: 10.1016/j.eswa.2011.04.096.

Zhu, J. (2000) "Multi-Factor Performance Measure Model With An Application To Fortune 500 Companies", European Journal of Operational Research, Vol. 123, No. 1, pp. 105-124, doi: 10.1016/S0377-2217(99)00096-X.

\title{
Procjena učinkovitosti ekonomije znanja: usporedba Turske s državama Europske unije
}

\author{
Tuba Yakıcı Ayan ${ }^{1}$, Hakan Pabuçcu ${ }^{2}$
}

\begin{abstract}
Sažetak
Ekonomija znanja je ekonomija koja proizvodi, distribuira $i$ koristi informacije. Danas ulaganje u kvalitetne informacije, a ne kapitalne inpute postaje sve važnije za razvoj zemalja i njihovu sposobnost da se međusobno natječu. Sve veće ubrzanje u stvaranju i širenju znanja pretvorilo je znanje u ključnu komponentu gospodarskog razvoja. Cinjenica je da zemlje koje imaju velika ulaganja u informacijske sustave, imaju brzi i održivi rast te su najdinamičnije i najkonkurentnije zemlje u svijetu. DEA se u ovom radu koristi za mjerenje relativne učinkovitosti zemalja Europske unije (EU), uključujući Tursku, politiku ekonomije znanja koja se temelji na podacima iz 2016. godine. Osim toga, implementiran je faktorski specifični DEA model kako bi se u kratkom roku identificirali ostvarivi ciljevi proizvodnje za svaku zemlju ponaosob. U analizi su korištena četiri outputa i tri inputa. Rezultati su jasno pokazali da je Njemačka ispred drugih zemalja. Njemačku slijede Francuska, Engleska, Malta i Nizozemska. Turska, s druge strane, odvojena je od drugih zemalja i najmanje je učinkovita. Razlog tog razdvajanja je da Turska proizvodi manje od očekivanog u odnosu na svoje resurse. Drugi je zaključak rada da su patentne prijave zemalja i izvoz visoke tehnologije neučinkovitije u usporedbi s ostalim proizvodima ekonomije znanja.
\end{abstract}

Ključne riječi: ekonomija znanja, učinkovitost, kontekstni APE, faktorski specifični $A P E$

JEL klasifikacija: C61, O57

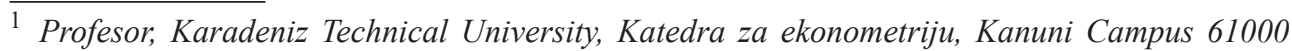
Trabzon, Turska. Znanstveni interes: matematički modeli, heurističko-metaheurističko pretraživanje, odlučivanje. Tel.: +090462 37730 00. Fax: +090 46232532 05. E-mail: ayan@ktu.edu.tr.

2 Doktor znanosti, Bayburt University, Katedra za poslovnu ekonomiju, Dede Korkut Campus 69000 Bayburt, Turska. Znanstveni interes: strojno učenje, neizrazita logika, analiza vremenskih serija.Tel.: +09045821111 74.Fax:+0904582111173.E-mail: hpabuccu@bayburt.edu.tr. (osoba za kontakt). 